\title{
A Strategic Policy Initiative for the Post-relocation of Street Vendors: Case of Surakarta, Indonesia
}

\author{
Anggraeni Permatasari \\ President University, Jababeka-Bekasi, Indonesia \\ anggraeni@president.ac.id
}

\begin{abstract}
Street vendors have emerged as a form of social response to maintain the survival of communities in going through economic challenges. However, street vendors have begun to have an uncontrolled growth; hence create social issues, particularly in large cities. In Surakarta, Indonesia, the relocation process of street vendors has been successfully executed by the municipal government. They have successfully managed to make street vendors agree to peacefully move to another area. Apparently, the relocation program is only sustained for several years. Most of street vendors have returned to their previous location, creating a huge chronic problem. This brief study aims at utilizing system thinking approach, using a causal loop diagram, to provide a framework for managing changes and complexity in the relocation process and to identify strategic indicators that may occur after relocation. The results are expected to contribute a defined framework for decision making process based on an analysis over the complex and dynamic systems of the relocation program. The results indicate that the municipal government of Surakarta may need to begin to formulate innovative activities through an improved public education and an enhanced street vendors' empowerment.
\end{abstract}

\section{Keywords: Street Vendors, Post-relocation, System Thinking, Causal Loop Diagram}

\section{Introduction}

Surakarta is a municipal located in the Central Java province, Indonesia. The municipality has been known by its marketing tagline "the Spirit of Java" due to its eco-cultural assets. Historically, it was first established in 1946, covering an area of 4,406.06 ha. Administratively, the municipality consists of five subdistricts, i.e. Laweyan, Serengan, Pasar Kliwon, Jebres and Banjarsari. During the last ten years, Surakarta has rapidly grown many sectors within its jurisdiction, e.g. industry, services, education, housing, tourism and trade. During 2003-2010 the number of street vendors in Surakarta tend to decrease; however, since 2010 the number has begun to increase over time. In 2012, the number of street vendors in Surakarta has reached 2,950 people. Looking at these figures, the municipal government began to see the phenomenon of street vendors as having a potential value to the development of informal economy sector. In the same year, the municipal government received the Best City Award in the conference of Partnership for Democratic Local Governance in Southeast Asia (DELGOSEA), Bangkok, Thailand. The award was obviously a clear appreciatiation over the relocation policy of street vendors. However, the government also began to realize that there are complex problems that occur after the relocation program. In fact, as stated by Sterman (2002), "... $(t)$ he most cases of policy resistance arise from dynamic complexity, the often counterintuitive behavior of complex systems that emerges from the interactions of the agents over time."

Theoretically, street vendors have been recognized as people who may have contributed to economic development through informal sectors. In Surakarta, the municipal government has been trying to develop economic activities of the informal sector by empowering street vendors. It facilitates activities that are not covered by law but publicly have a track of production activities, e.g. property, production capacity, contracts, and related taxes. Informal economy itself refers to "all economic activities by workers and economic units that are in law or in practice not covered or insufficiently covered by formal arrangements" (ILO, 2007). The sector basically does not have a negative connotation, but has in fact often been recognized as promoting ilegal activities into the economic development of a country. Meanwhile, Kayuni \& Tambulasi (2009) have stated that there is a strong relationship between formal and informal sectors. In other words, informal sector has a possibility to develop, same as formal sector. Besides, informal sectors may actually impact to the increase of regional revenues. Therefore, the municipal government of Surakarta has to cooperate with street vendors in 
a two-ways partnership in developing and controlling the growth of informal sector. This research aims at developing a policy framework over the challenges met by either local government or private stakeholders who share the responsibility of sustaining the informal sector. In particular, this paper attempts to look at the complex problem of street vendors in a holistic way for proposing a framework for strategic policy initiatives, which may act as anticipation to any negative impacts after the relocation program of street vendors.

\section{Literature Review}

System Thinking: As the resistance to a policy being implemented has become a critical concern in any ongoing policy development, it is important to understand the root cause of a resistance. Sterman (2002) has stated that “... (p)olicy resistance most often arises because our mental models systematically lead us to incorrect inferences about the dynamics of even the simplest systems". System itself refers to interconnected elements that have constructed a specific behavior in a given period of time. Besides, it has particular function and purpose. Based on these understandings, system thinking supposedly refers to the ability of understanding and influencing a complex system. Anderson \& Johnson (1997) have revealed practical guidance of system thinking since its conceptual understandings to building causal loops. In particular, they establish the guidance based on the understanding of a system as "...(a) group of interacting, interrelated or interdependent components that form a complex and unfied holistic. System Thinking is a language, too, that offers a way to communicate about dynamic complexities and interdependencies" (Anderson \& Johnson, 1997).

Furthermore, system thinking is purposely designed to help people to see the reality of a complex situation that occurs in a dynamic way. The method focuses on a holistic point of view and attempts to recognize the relationships between problems as a path. The steps of building a system thinking analysis include:

a) Take a look at potential formulas

b) Identify key variables and possible main actors within the structure of a system.

c) Create a chart of variables based on their Behaviour Over Time (BOT)

d) Identify the structure of system to establish a causal loop diagram (CLD)

The principles of system thinking include: (1) thinking broadly; (2) balancing short and long term perspectives; (3) recognizing the natural system as a dynamic, complex, and interdependent; and (4) counting on factors being measured. A system thinking process begins with an iceberg phenomenon. The phenomenon is a distinguished way to see problems in a deeper manner. Practically, a problem is constructed from its pattern of behavior; the pattern of behavior will then be structured and hence form a system. The structure is basically developed from a particular approach in system thinking, which is widely known as a mental model as the basis of a problem (Figure 1).

Figure 1: Iceberg Phenomenon

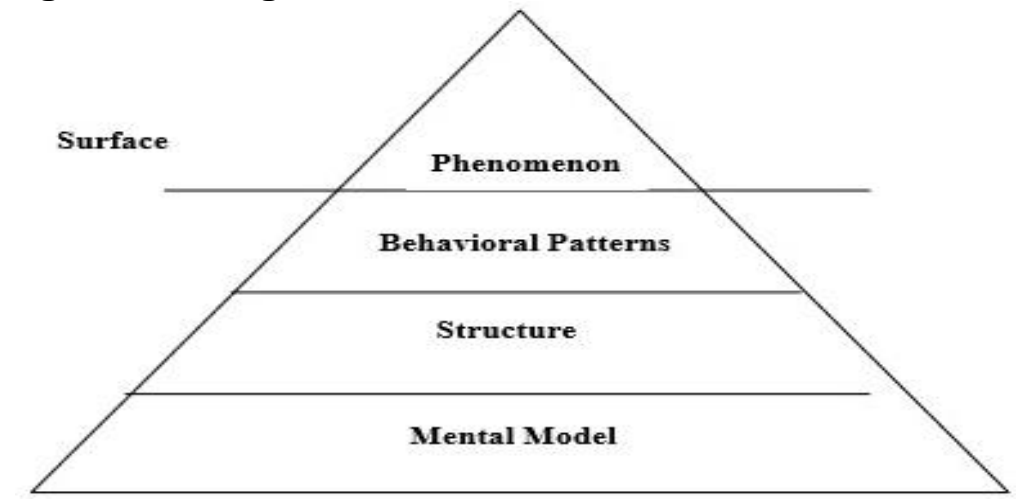

Source: Anderson and Johnson 1997

In addition, Richardson (1998) has stated that “...(b)ehavior over time graphs help people to focus on patterns of change over time rather than on single events. They help students think about the underlying causes of those 
changes". In other words, BOT GRAPHs function is useful to see the variables or indicators influencing a problem in the pattern of behavior based on different timescales. The scales may determine behavioral trends. A BOT chart requires three things, i.e. indicators/variables, timespans and resource-perspective trends. On the other hand, CLD is used to find a leverage point as the strategic indicator to change an existing system. Thus, CLD function is supposed to formulate a strategic indicator of things for being conducted in a long run to have a significant impact on a system. It includes strategic planning, formulating arguments of activities, formulating strategic objectives and sub-objectives, and formulating subsequent activities. Practically, CLD has four creation steps, i.e. (1) listing variables or indicators that are considered important; (2) thinking and writing down the reasons why they occur and what consequences that will appear; (3) creating the cause-and-effect pattern between variables/indicators that form a CLD; and (4) checking BOT again, expanding the CLD until there is no more relationship.

Street Vendors Relocation Program: The existence of street vendors in Indonesia is frequently assumed as an issue of illegal business activities, and hence treated as a crime. Street vendors have no legal status to operate their businesses, and therefore continuously disturbed by the authority. In fact, the proliferating activities of street vendors may cause a chaos over public facilities. Basically, the large number of street vendors in Indonesia is triggered by several motivations, i.e. 1) the increase of labor force in a city; 2) a limited number of employment opportunities in the city, 3) a percentage discrepancy between labor force and employments, 4) an excessive number of urban migration to big cities (Mitullah, 2003; Chen 2005; Permatasari et al., 2014). Furthermore, the relocation program of street vendors refers to a process to move street vendors' trading site from a public space that has been determined by government as a prohibited site for any trading activities (Setia, 2009). Street vendors basically resist a relocation program because they need a direct access to actual and potential clients. Besides, their activity has become a major source of livelihood. Then, there is an effort by municipal authorities to evict them as a violation of their fundamental human rights (Kayuni \& Tambulasi (2009). Thus, relocating street vendors requires sinergy and integration between stakeholders and developmental sectors, because "the government's major challenge was how to control street vending so that it shouldn't negatively affect the development of its urban center" (Kayuni \&Tambulasi, 2009).

\section{Methodology}

This study aims at analyzing broader issues of the dynamic and complex phenomenon of street vendors in Surakarta, with a particular focus on the impact after relocation process. System thinking with causal loop diagram is taken in conducting the analysis. System thinking itself is taken due to its potential capability in dealing with complexity, ambiguity and mental models underlying the presence of most social, economic, ecological, and political challenges (Anderson \& Johnson, 1997; Sterman, 2002; Thanh \& Kambiz, 2015). System thinking analysis is helpful to find potential problems that that may arise after the relocation of street vendors. This research takes trends as secondary data to analyze variables/indicators in creating Causal Loop Diagram (CLD). The CLD is taken to see the leverage points within the complexity of post-relocation problems (Anderson \& Johnson, 1997). Besides, it is taken to develop the framework of strategic variables for being used as intervening variables in any strategic policy initiative during the post-relocation of street vendors.

\section{Result \& Analysis}

The Post-relocation of Street Vendors: The existence of street vendors triggers several negative impacts, e.g. traffic jam and infrastructure chaos, etc. On the other hand, it offers a positive impact to the increase of informal economic growth. In general, street vendors are known as people who offer their goods and services for sale in a public area, especially on the pedestrian or main road area (Mitullah, 2003; Chen, 2005). In fact, being a street vendor is considerably an employment opportunity. Street vending is manageable by people as their self-sufficient income sources, usually without either possessing the possession or a clear legal status. The complex dilemmatic challenges have triggered the intervention by Surakarta municipal government to solve the dynamic system in the phenomenon of street vendors. After the infamous relocation program, the municipality meets further issues that requires strategic solutions. The main issues after the relocation program is founded on the emerging dynamic complexities, e.g. the increasing number of population and poverty, and the limited number of jobs availability and educated people. 
Population and poverty: According to a socio-economic survey conducted in 2011, the population density in Surakarta was 13,354 persons $/ \mathrm{km}^{2}$. Meanwhile, the population in 2010 was 503,421 people, with a dependency rate at 66 per cent. Records from the 1880 census indicated the population of 124,041 inhabitants. Population has grown around 0.565 per cent per year in the last 10 years. With its population density, Surakarta has the highest density of inhabitants in Central Java (the average density in the province is 992 persons $/ \mathrm{km}^{2}$ ). At national level, Surakarta is the $8^{\text {th }}$ most populous city in Indonesia, despite having the $13^{\text {th }}$ smallest area, and the $22^{\text {nd }}$ most populated city among 93 municipalities and five administrative cities in the country. Furthermore, Pasar Kliwon is the most populous district in Surakarta, which covers one-tenth of its total area, while Laweyan is a district with the lowest density. During 2000-2010, the population growth of Surakarta was 0.25 per cent, well below the rate of population growth in Central Java $(0.46 \%)$. Kompas News (2011) in an article "Increased Population Becoming Threat" has indicated that Indonesia's population has been worryingly increasing, amounting to approximately 240 million people with a 1.49 per cent growth rate. It is stated as having a serious threat because due to the low human quality. If it is not properly controlled, the growth may bring some further impacts, especially on the availability of food, energy, and education as well as health services.

Jobs Availability and Job Seeker. In improving the economic growth of informal sectors, Surakarta municipal government has created a set of policies to support the creation and expansion of employment opportunities. However, there is in fact an unbalanced situation between demand and supply in the labor market. Vacancies tend to be getting bigger than job availibility, job seekers or unemployment (Figure 2).

\section{Figure 2. Surakarta: Job Seeker, Vacancies, Availability versus Education Level in 2011}
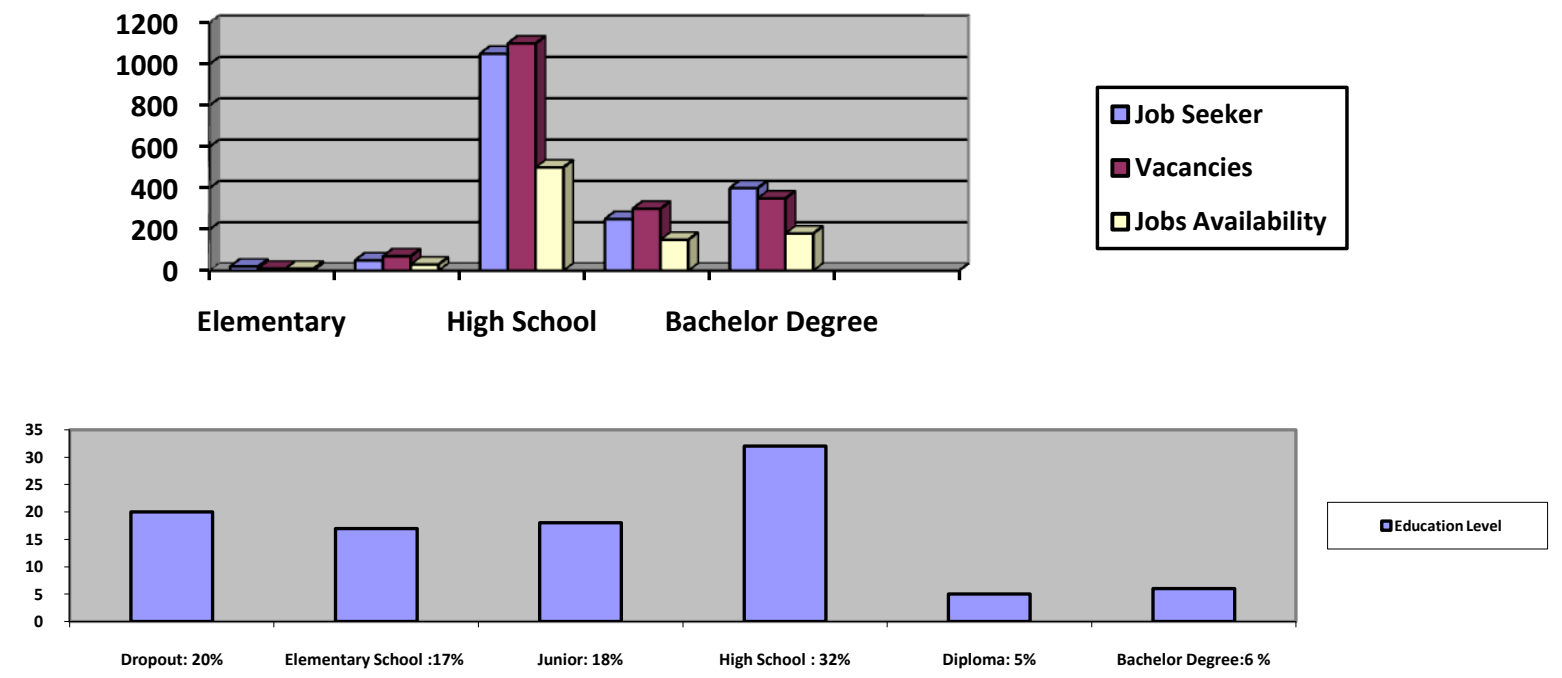

Source: www.bps-surakarta.go.id

The condition indicates a need to put a serious concern due to the less number of additional vacancies available, while the number of employed workforce is too small. Required solutions may regard to why people who are looking for a work cannot be recruited following available vacancies. The number of residents who work within the city of Surakarta in 2011 was 249.368 people, covering 49.71 per cent of the entire town population.

Education: Low educational level and the lack of jobs available have encouraged rural people to migrate from their villages to large cities (urbanization). However, the presence of villagers in large cities is not properly supported by a sufficient human capacity and expertise. Thus, it is difficult for them to get a decent job (Figure 2). In fact, the particular reasons may have explained why becoming street vendors has been the first 
option for a living (Wijayanti, 2011). Solopos News (2011) in an article "Overcoming unemployment, educational institutions altered composition" write that the municipal government of Surakarta may have been changing the applicable education policy in Indonesia. The policy is expected to overcome the problem of high unemployment. It was first announced by Atmojo Dwi H. as the Head of High and Vocational School Division, the Agency of Education, the District of Sukoharjo. In a following article, Anung I. Susanto as the Head of the Regional Development Planning Board (Bappeda), the Government of Surakarta stated that "...(o)ne of the efforts that has been implemented to reduce poverty is a governmental intervention conducted by the government in education, health and social services."

Causal Loop Diagram: The map of events occurred in the community is possible to explore through a causal loop diagram. Causal loop diagram shows that number of educated people is a strategic point indicator as the leverage point for the dynamic problem being investigated over street vendors. The increasing number of educated people would enhance the skills and capabilities of quality people. The effect of such a strategic indicator would cause the decreasing number of unemployments/job seekers, because the community members may get recruited according to their expertise. The decreasing number of unemployment or job seekers would then reduce the number of street vendors. At a higher level, the availability of job opportunities in Surakarta may indicate a good opportunity for other large cities in reducing the number of street vendors in their own regions. On the other hand, the availability of decent jobs would make people to have a higher income in parallel with the economic growth. The growth would then decrease the number of poverty. It seems that if the number of poverty has decreased following the economic growth, people may pay for the education cost of their children. At the government level, economic growth would support the increase of regional revenues in the municipality of Surakarta, meaning that the government would have more budget allocation to create further strategic policy planning for all levels of education (Figure 3).

\section{Figure 3: Causal Loop Diagram for the Relocation of Street Vendors}

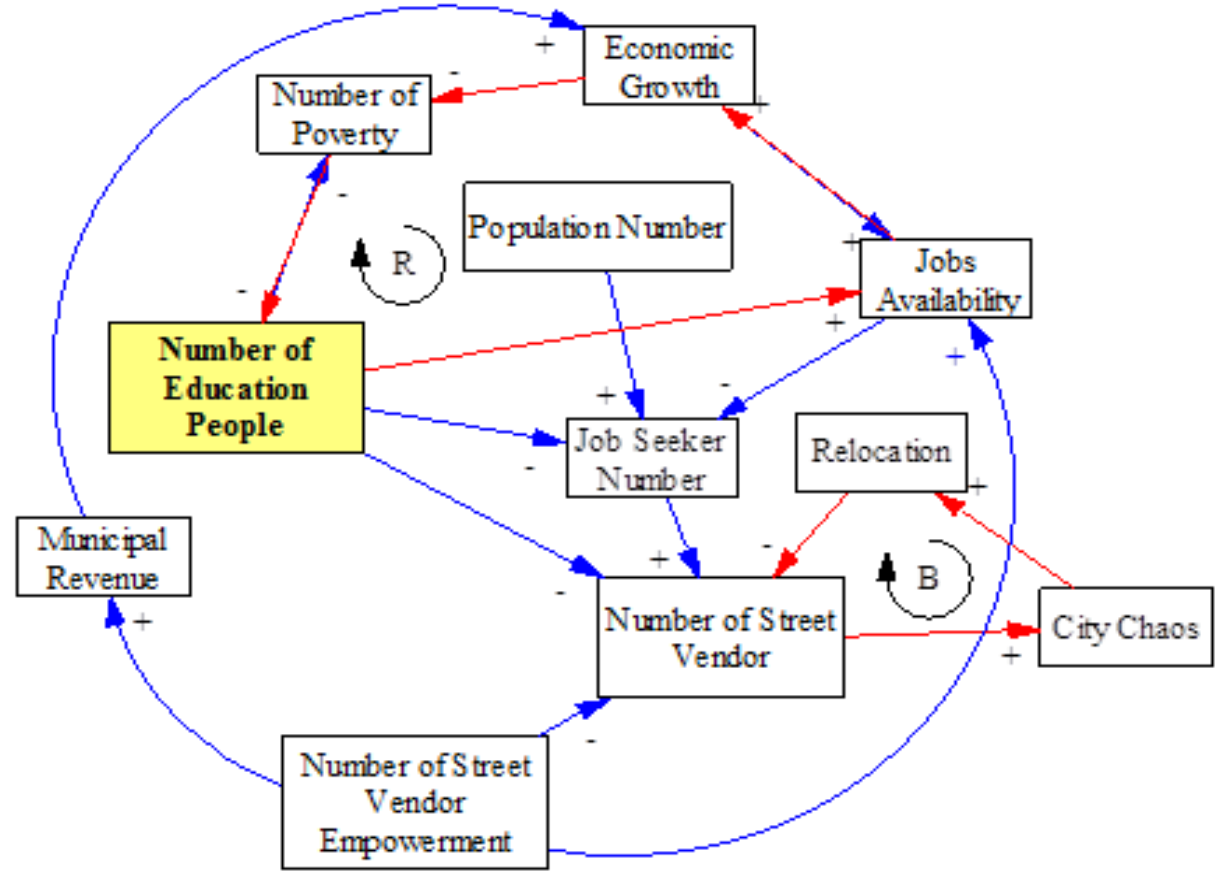

Notes: S/+: Similar, O/-: Opposite, R: Reinforcement, B: Balancing

The decreasing number of educated people may have directly caused the increasing the number of street vendors and a variety of other problems, e.g. poverty and job seekers. Next, there are several factors influencing the decline of education in Indonesia. i.e. physical facilities, low quality of teachers, lack of opportunities, lack of relevant educations, low vision, low moral knowledge, and high education cost. If the government puts a further intervention towards education, it would automatically and actively affect all 
existing variables in the causal loop diagram. Hence, problems related to street vendors would gradually be resolved. As a following step, municipal government may need to start to think about any activities, including interventions, required to properly enhance the educational level of the community in Surakarta. From the results of causal loop diagram analysis (Figure 4), it seems there is a causal relationship between indicators of street vendors' dynamics that indicate a reinforcing loop (R). At the first loop diagram, the number of street vendors is seen as a potential driver to an empowered economy of the people. A nurtured empowerment would positively contribute to the regional revenues of the municipality. With the increase of regional revenues, the government of Surakarta has an opportunity to increase the budget allocation for future empowerment programs for street vendors. In other words, street vendors may have a sustained opportunity to promote and grow their businesses (Thayrun, 2012). It is interesting to reveal that there is a causal relationship among indicators in the Figure 4, forming a mutually reinforcing system. Each indicator has been contributing to the success of other indicators. In fact, those interrelated indicators form a circular copy of causal relationship, whether it is strengthening or weakening each other. In Hikmawan's work (2011), education has been stated as having a critical importance to a nation's competitiveness. Besides, education is a key solution for eradicating poverty in medium and long terms. In other words, education is the path to the progress and achievement of social and economic welfare.

Figure 4: Strategic Policy Initiative for the Post-relocation of Street Vendors

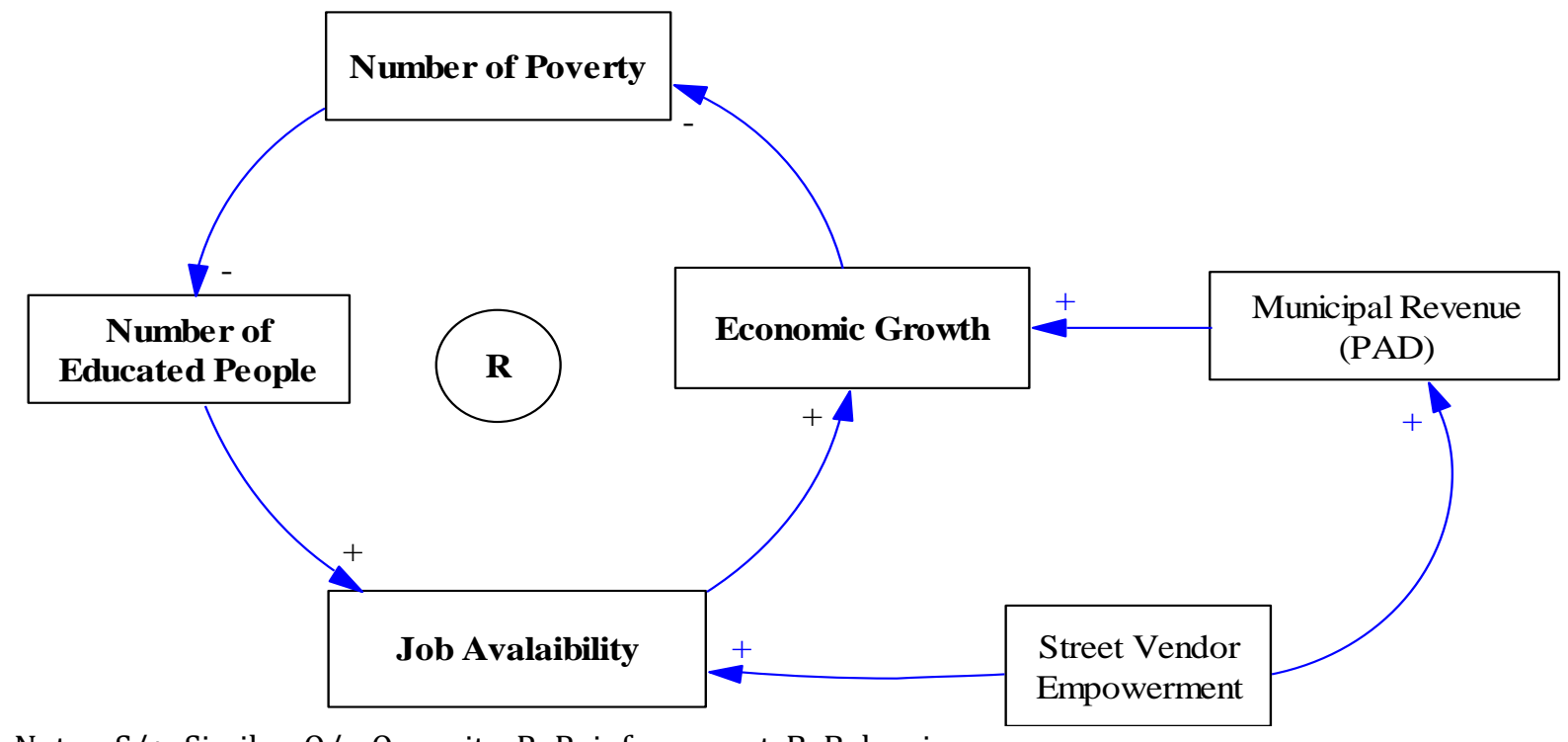

Notes: S/+: Similar, O/-: Opposite, R: Reinforcement, B: Balancing

\section{Conclusions and Implications}

Systems thinking is taken to view a problem through a holistic point of view. Based on a system thinking analysis, policy makers may see the problem as widespread and intact. This brief study attempts to explain the complex and dynamic model of relocation program in Surakarta. The model is supposed for being developed further, and may therefore contribute in the form of a framework for decision making. Besides, it may support the capacity development for local government and private stakeholders or stakeholders who share the responsibility of sustaining the system. Looking at the proposed system thinking analysis, the municipal government of Surakarta may begin to formulate innovative activities for improving the public education sector and empowering street vendors. The particular focuses on education and empowerment programs are purposely taken to improve the capabilities of street vendors in fulfilling the gap of job availabilities. Besides, it clearly aims that every strategic policy analysis that is founded system thinking approach may produce an opportunity to gain feedback in creating dynamic effects of the system in a longer term after the relocation process. 


\section{References}

Anderson, V. \& Johnson, L. (1997). System Thinking Basics: From Concepts to Causal Loops, Pegasus Communications, Inc

Buletin Tata Ruang. (2010). Tokoh Profil: Ir. Joko Widodo Jadikan Solo Eco Culture City,

BPS Kota Surakarta. (2011). Surakarta dalam Angka 2011. Surakarta, BPS.

Chen, M. (2005). The Business Environment and the Informal Economy: Creating Conditions for Poverty Reduction. Draft Paper for Committe of Donor Agencies for Small Enterprise Development Conference on Reforming te Business Environment, November 2005, Cairo, Egypt.

Hikmawan, P. (2011). Kebijakan Pendidikan bagi Masyarakat Miskin. Available at http://hikmawansp.wordpress.com

ILO. (2007). Labour and Social Trends in Asean 2007: Integration, Challenges and Opportunities. Bangkok: ILO.

Kayuni, H. M. \& Tambulasi, R. I. C. (2009) Political Transitions and Vulnerability of Street Vending in Malawi, Theoritical and Empirical Researches in Urban Management.

Mitullah, W. V. (2003). Street Trade In Kenya The Contribution Of Research in Policy Dialogue and Response. Paper Prepared for Presentation at the Urban Research Symposium on Urban Development for Economic Growth and Poverty Reduction. Sessions on Dimensions of Poverty and Livelihoods, Group C on Informal Economy, Panel on Urban Responses to Street Traders: A comparative Perspective from India, Kenya an South Africa; Organized by the World Bank, Washington, DC.

Permatasari, A., Putro, U. S. \& Nuraeni, S. (2014). Strategic Analysis Relocating Street Vendor through 3D Negotiation Case Study : Street Vendor Surakarta, Indonesia. Procedia - Social and Behavioral Sciences, 115, 436-443.

Puspita, H. S. D. (2007). Demokrasi Imajinasi dalam petanahan. Jurnal Hukum dan Pembangunan, 37(3).

Richardson, G. (1998). Getting Started with Behavior Over Time Graphs, Creative Learning Exchange

Setia, R. M. (2009). Ekonomi Informal Perkotaan: Sebuah Kasus Tentang Pedagang Kaki Lima Di Kota Bandung. Jurnal Analisis Sosial, 14(1).

Sterman, J. D. (2002). System Dynamics: Systems Thinking and Modeling for a Complex World, Working Paper Version, Massachusetts Institute of Technology Engineering Systems Division.

Thanh, V. M. \& Kambiz, M. (2007). Systems Thinking for Sustainable Tourism in the Cat Ba Biosphere Reserve of Viet Nam, School of Integrative Systems The University of Queensland, Australia.

Thayrun, Y. (2012). Jokowi Pemimpin Rakyat Berjiwa Rocker, Noura Books, Jakarta.

Wijayanti, A. R. (2011). Studi Kasus Relokasi PKL Monumen 45 Banjarsari dan Peran Mahasiswa Perencanaan Wilayah dan Kota dalam Usaha Mewujudkan Keberhasilan Pembangunan Kota, Makalah KOMPI. 